Members. Anguilla, Antigua and Barbuda, Dominica, Grenada, Montserrat, St Kitts and Nevis, St Lucia, St Vincent and the Grenadines.

Official language: English.

Headquarters: PO Box 89, Bird Rock, Basseterre, St Kitts and Nevis.

Website: http://www.eccb-centralbank.org

Email: info@eccb-centralbank.org

Governor: Sir Dwight Venner (St Vincent and the Grenadines).

\section{Inter-American Development Bank (IDB)}

The IDB, the oldest and largest regional multilateral development institution, was established in 1959 to help accelerate economic and social development in Latin America and the Caribbean. The Bank's original membership included 19 Latin American and Caribbean countries and the USA. Today, membership totals 48 nations, including non-regional members.

Members. Argentina, Austria, Bahamas, Barbados, Belgium, Belize, Bolivia, Brazil, Canada, Chile, China, Colombia, Costa Rica, Croatia, Denmark, Dominican Republic, Ecuador, El Salvador, Finland, France, Germany, Guatemala, Guyana, Haiti, Honduras, Israel, Italy, Jamaica, Japan, South Korea, Mexico, the Netherlands, Nicaragua, Norway, Panama, Paraguay, Peru, Portugal, Slovenia, Spain, Suriname, Sweden, Switzerland, Trinidad and Tobago, UK, USA, Uruguay, Venezuela.

The Bank's total lending up to 2007 was US\$156bn. for projects with a total cost of over US $\$ 353 \mathrm{bn}$. Its lending increased dramatically from the US $\$ 294 \mathrm{~m}$. approved in 1961 to US $\$ 8,970 \mathrm{~m}$. in 2007.

Current lending priorities include poverty reduction and social equity, modernization and integration, and the environment. The Bank has a Fund for Special Operations for lending on concessional terms for projects in countries classified as economically less developed. An additional facility, the Multilateral Investment Fund (MIF), was created in 1992 to help promote and accelerate investment reforms and private-sector development throughout the region.

The Board of Governors is the Bank's highest authority. Governors are usually Ministers of Finance, Presidents of Central Banks or officers of comparable rank. The IDB has country offices in each of its borrowing countries, and in Paris and Tokyo.

Official languages: English, French, Portuguese, Spanish.

Headquarters: 1300 New York Avenue, NW, Washington, D.C., 20577, USA.

Website: http://www.iadb.org

President: Luis Alberto Moreno (Colombia).

\section{Latin American Economic System (SELA)}

Established in 1975 by the Panama Convention, SELA (Sistema Económico Latinoamericano) promotes co-ordination on economic issues and social development among the countries of Latin America and the Caribbean.

Members. Argentina, Bahamas, Barbados, Belize, Bolivia, Brazil, Chile, Colombia, Costa Rica, Cuba, Dominican Republic, Ecuador, El Salvador, Grenada, Guatemala, Guyana, Haiti, Honduras, Jamaica, Mexico, Nicaragua, Panama, Paraguay, Peru, Suriname, Trinidad and Tobago, Uruguay, Venezuela.
Official languages: English, French, Portuguese, Spanish.

Headquarters: Av. Francisco de Miranda, Torre Europa, Piso 4, Urb. Campo Alegre, Caracas 1060, Venezuela.

Website: http://www.sela.org

Permanent Secretary: José Rivera Banuet (Mexico).

Publications. Capitulos (in Spanish and English, published thrice yearly); SELA Antenna in the United States (quarterly bulletin); Integration Bulletin on Latin America and the Caribbean (monthly).

\section{Latin American Integration Association (ALADI/LAIA)}

The ALADI was established to promote freer trade among member countries in the region.

Members. (12) Argentina, Bolivia, Brazil, Chile, Colombia, Cuba, Ecuador, Mexico, Paraguay, Peru, Uruguay and Venezuela.

Observers. (28) Andean Development Corporation (CAF), China, Commission of the European Communities, Costa Rica, Dominican Republic, El Salvador, Guatemala, Honduras, Ibero-American General Secretariat (SEGIB), Inter-American Development Bank, Inter-American Institute for Cooperation on Agriculture (IICA), Italy, Japan, South Korea, Latin American Economic System (SELA), Nicaragua, Organization of American States (OAS), Pan American Health Organization (PAHO), Panama, Portugal, Romania, Russia, Spain, Switzerland, Ukraine, UN Development Programme, UN Economic Commission for Latin America and the Caribbean (ECLAC), World Health Organization (WHO).

Official languages: Portuguese, Spanish.

Headquarters: Calle Cebollatí 1461, Casilla de Correos 20005, 11200 Montevideo, Uruguay.

Website: http://www.aladi.org

Secretary-General: Hugo Saguier Caballero (Paraguay).

\section{Latin American Reserve Fund}

Established in 1991 as successor to the Andean Reserve Fund, the Latin American Reserve Fund assists in correcting payment imbalances through loans with terms of up to four years and guarantees extended to members, to co-ordinate their monetary, exchange and financial policies and to promote the liberalization of trade and payments in the Andean sub-region.

Members. Bolivia, Colombia, Costa Rica, Ecuador, Peru, Uruguay, Venezuela.

Official language: Spanish.

Headquarters: Edificio Banco de Occidente, Carrera 13, No.

27-47, Piso 10, Santafe de Bogota, DC, Colombia.

Website: http://www.flar.net

Executive President (acting): Ana María Carrasquilla

(Colombia).

\section{Organisation of Eastern Caribbean States (OECS)}

Founded in 1981 when seven eastern Caribbean states signed the Treaty of Basseterre agreeing to co-operate with each other to promote unity and solidarity among the members. 